\title{
Transformation of the Subject in the Act \\ of the Reverse birth: Analysis \\ of the Search of the Lost Mother \\ (based on A. Platonov's Texts)
}

\author{
Olga A. Glushenkova* \\ Siberian State Technological University \\ 57 Markovskogo Str., Krasnoyarsk, 660017, Russia
}

Received 01.02.2016, received in revised form 18.03.2016, accepted 20.04.2016

\begin{abstract}
The article is dedicated to the ontological analysis of A. Platonov's texts. The classical theme of orphancy, raised by the writer, is analyzed through the definitions of J. Kristeva about searching of the lost motherly. The problem of the displacement of the mother by European rationality leaves open the question of the status of this "repressed" space. In the analysis of the text, it is represented by the concept of Michel Foucault that is heterotopia, for conceptualizing the hidden, repressed space of the mother in the text. The article analyzes the desire to overcome the orphancy by central characters in "Dzhan" and "Chevengur", which are emotionally various texts, not in the trivial context of the connection with the father, but with regard to the search of the mother and the realization of her finding - the return to the womb that is the connection between the process of birth and the symbolic overcoming of death. The author approves the use of the categorical framework of psychoanalysis and philosophical concepts in the analysis of a literary text. The difference between the two texts analyzed in the process of overcoming orphancy represents the desire to build a happy utopia in the Soviet reality of the conflicting 30 s.
\end{abstract}

Keywords: heterotopia, A. Platonov, psychoanalysis, Soviet reality.

DOI: 10.17516/1997-1370-2016-9-5-1109-1115.

Research area: philology.

\section{Introduction}

The works of A. Platonov represent a rich material for researchers: A. Platonov, the author of the works "The Foundation Pit" and "Chevengur", called a "misunderstood" writer, is still unsolved. The main period of his work was during the transition phase in the history of our country that is the $20 \mathrm{~s}$ and $30 \mathrm{~s}$, and during the formation of a political giant - the Soviet Union. In such circumstances, any work must be ideologically marked by consent or rebellion of indignation, acceptance or at least a tacit disapproval. It is impossible to refer A. Platonov to any of the political extremes. Furthermore, his works can not be called ideologically neutral which allow tracing the change in the attitude of the writer towards the authorities. The "funeral" text of "The Foundation Pit" was written at the same time as

(C) Siberian Federal University. All rights reserved

* Corresponding author E-mail address: netzumi@mail.ru 
the optimistic story "Dzhan", while a politically controversial novel "Happy Moscow" even runs through all the work of the writer. The inability to refer A. Platonov literally to neither opponents of the Soviet nor ideologically loyal writers forces to delve into the analysis of Platonov's symbols and cultural parallels. Besides, a special attention should be paid to a special writer's language that is deliberately wrong, full of bureaucratic style and countless abbreviations generated by the Soviet power. Platonov's language is the key to understanding the art philosophy of the writer, called "the language of life" by M. Epshtein (Epshtein M., 2006). Combined with the cultural codes that are displayed in the works, it forms the space of the text, a kind of mirror or heterotopia, representing the Soviet era.

\section{Theoretical framework}

The concept of heterotopia was first offered by M. Foucault in "Other spaces" (Foucault M., 1984, 46-49), arguing that each culture creates heterotopia and each heterotopia may begin to function in another way at the change in the general synchrony of culture. What is most important, heterotopia may include some incompatible spaces, some locations, which are not compatible by themselves. In the analysis of the text's space positions are a way to express meanings, that are often contradictory, which is typical for the works of "misunderstood" A. Platonov. That is why the concept of heterotopia is optimal for the analysis of the writer's texts. A special attention should be paid to psychoanalytic motives: the interaction of protagonists and antagonists in the works, their meaning merger with text spaces in the spirit of the classic Freudian division of the psyche into "Id, Ego, Super-Ego" allow using the categorial concepts of psychoanalysis. A heterotopic analysis allows us to take the thesis of "the changes in the general synchrony of culture" (Foucault M., 1984, 46), which means, it legitimizes the psychoanalytic reading of A. Platonov, despite the open question about whether the writer was familiar with the research of Freud.

\section{Statement of the problem}

The motive of "the return to the womb" runs through all the work of the writer. A kind of a reverse birth appears in texts both literally as in the story "Dzhan":

"In your stomach? - Nazar asked. - Why didn't you leave me there?" (Platonov A.P., 2008, 6)

and symbolically as in" Chevengur ", where the central character plunges into a lake, symbolizing the dark mother origin:

Alexander Dvanov "himself lighted off a horse into the water in search of the road which once his father had taken curiously wishing to see the death" (Platonov A.P., 2008).

Such symbolic constructs refer the French researcher J. Kristeva to the categorial concepts about the importance of the mother. The analysis of "reverse birth" phenomenon through the concept of the search of the lost mother by J. Kristeva allows considering the marker of A. Platonov's texts that has already established in literary studies as permeated with the motive of orphancy in a deeper way (Spiridonova I.A., 1998, 515). Orphancy defines itself by a through image of the father, whose role is played by the leader taking care of all. Unattainable in the material reality, he appears to the heroes in the form of portraits, sometimes being impersonal and dissolving in the idea of communism.

A heterotopic text analysis allows us to take into account the synchrony of the modern culture and use, firstly, the categorial concepts of psychoanalysis in the texts of A. Platonov, and secondly, combine the literal father origin with concealed mother one and take a fresh look at the problem of overcoming orphancy. The significant problem is also a question about overcoming 
death and the end of the story through the "search of the lost mother" or a literal return to the womb. Some utopian motives of eternal life going with the abundance and communism in A. Platonov's works are obvious, but the very ontological overcoming of death in the text is associated with the motherly or "repressed", in the terminology of J. Kristeva.

\section{Discussion}

The return to the womb, or "reverse birth" has a profound eschatological significance of eternal life, another life, and overcoming death as the death of the soul in A. Platonov's works. "It's good for those who died in their mother", Giul'chatai says to his son in the novel "Dzhan" (Platonov A. P., 2008, 6). The process of dying involves pre-birth and life, in this case it comes to an end before it begins. The idea of birth is associated with the separation from the mother, coming to the world with the ability to live outside the womb, where maturation and preparation for future life occur. Literally, the phrase of the Turkmen woman is completely pointless, that is why the text of A. Platonov directs us much deeper, namely to the idea of "not a birth, but existence" that protects from death immediately after birth. The response of Giul'chatai's son, Nazar, confirms this, "I would have died, and I would not be here now, and you would eat and live and think of me that I was deliberately alive" (Platonov A. P., 2008, 6). Having a baby is literally the process of separation from the mother. But the formation of the subject comes later, in an act of separation from the mother and the child's awareness of their own self. This process is gradual and occurs, according to J. Kristeva, in giving not the mother but her absence to the child. Thus, creating a space for thought, the mother allows the child to become aware of himself, but his cogito does not clean a separate place, but replaces the mother passion, forcing it out. M. Nikolchina, the researcher of J. Kristeva, calls the place of the departed mother passion "a hidden space" or the female "swallowed" where rationality is born. The swallowed appeals to the Greek myth of the Metis, the goddess of wisdom, who was swallowed by Zeus for fear that the child born by her can transcend him. Being inside Zeus, Metis is his advisor, who announces to him what evil is and what good is. The myth illustrates the alignment of the European father rationality on the "swallowed" space of the mother repressed. Indicated in the text, the "layers" of these spaces are exactly heterotopia. A. Platonov backs his heroes in the mother's space for gaining something inaccessible in rational material reality: A. Dvanov enters the lake, symbolizing a nursing mother, while Chagataev is surrounded by women and trusts his people to a pregnant girl because "a woman is often better than a man, and a mother is nicer or dearer than a father" (Platonov A.P., 2008, 20). But these spaces are different, as well as the nature of the texts: the space of a happy story "Dzhan" is mother by itself - Sary-Kamyshskaia depression, desert. The Dzhan people dig pits to find sand and chew it to quench their thirst, as a child looks for his mother's nipple to get sated. But the desert is poor in drink and food, as well as women, whose "breasts dry up, bones inside ache" (Platonov A.P., 2008, 8) and "fat dried up in all the joints" (Platonov A.P., 2008, 12). Nazar Chagataev is born in the space of the desert - in the mother. Moreover, the desert for him is "poor and native" (Platonov A.P., 2008, 17), as well as his mother. A symbolic representation of the mother in the space of the desert is clear as well as the associated formation of the personality of Nazar through the elimination of mother passion. Chagatai recalls how he had to leave his homeland: "A small Nazar did not want to leave his mother. He told her that he was used to dying and was no longer afraid that he would not have enough food. But the mother 
turned him back. - No, - she said. - I'm so weak that I can not love you any more, live alone now. I will forget you" (Platonov A.P., 2008, 12). In the Freudian understanding this process is presented as self-awareness as a separate person from the mother, in Kristeva's understanding it is deeper by "their gradual neutralization of passion and capacity for sublimation (Note - sublimation of mother passion) a mother gives her child an opportunity to represent not a mother, but her absence" (Nikolchina M, 2003, 42).

This creates a space for thought and, therefore, for the development of selfconsciousness, or rather for self-awareness. The way of Chagataev after parting with the mother by means of her sublimation - "I will forget you" - lies exactly to self-realization, the knowledge of objective reality and the laws of nature. In Moscow Nazar graduated from the Institute, "now ascended high on the mountain of his mind" (Platonov A.P., 2008, 1). The space of Moscow symbolizes his father: in Moscow the leader, taking care of all the people, lives, Moscow provides education and food for thought, inspires achievements. But Chagataev is seconded to his homeland in the desert to build socialism there and save the small "Dzhan" nation, which Nazar comes from. Chagataev does his job, although it is often difficult to rationalize his actions. He leads people somewhere in the desert, exhausted by hunger and thirst, and almost dies. In Khivy, leaving a girl Khanom in the teahouse, he promises her to come back in ten days or fifteen, but goes away with Suf'an to play the dutar to people and sing until the summer. Nazar's actions are not rational, and they should not be: his motherland is the womb in which he appeared, an archaic mother, terrifying by her generating force. The motherly is beyond syntax and logic, although it generates them. At the end of the story Chagataev returns to Moscow, completing his mission.
There is no such polarity in the space of "Chevengur" as in the story "Dzhan" that is the opposition of Moscow- Desert. It is fairly homogeneous, but the contrast is created by the aspirations of the two main characters Alexander Dvanov and Kopenkin. They are in search or follow their aims: Dvanov does it thinking about the meaning of all existence while Kopenkin firmly guides his horse to the grave of Rosa Luxemburg. Dvanov is an orphan; his father was a fisherman drowned "in the curiosity of death" (Platonov A.P., 2008, 26), leaving his son alone. The fisherman was already a widower, the mother of Alexander goes beyond the space of the novel, but her image emerges in Sonia a familiar girl who attracts Dvanov. But in such close terms as pleasure and death, he chooses the latter - not as a totality, what the end of the novel talks about with Proshka's promising to bring it. Dvanova is not satisfied with the rational, and this is the reason of his search, the desire to get the mother, "the culture is already an overgrown field where soils are taken by plants and where nothing else will ever grow" (Platonov A. P., 2008, 176). The quest for a new space, a new awareness of objective reality. He finds it in the waters of the lake. They do not cause dissatisfaction in the ever recurring desire like a woman. A deliberate lack of something erotic in the physical aspirations of the heroes does not purport their spirituality. Kopenkin asked Dvanov, "Was Comrade Liebknecht like a man for a woman for Rosa, or I was just thinking so?" (Platonov A. P., 2008, 154), and after receiving a negative answer, he is filled with even more affection for her. Rosa Luxemburg is dead and temporarily not able to satisfy a man's desire, provoking the new one. That is why the desire of Kopenkin is total, it is satisfied only once, in the act of reunification. Dying really - "lay dead, face down," he reunites with Rosa without fear of subsequent dissatisfaction. Overcoming his 
orphancy, Dvanov also refuses an alive woman, able to give temporary pleasure, preferring a symbolic return to the womb. "Dvanov pulled up to the water's edge. He bathed in it and got food from it in early life, once it calmed down his father in its depths" (Platonov A.P., 2008, 288) - this is an allusion to stay in the womb, "feeding in early life" (Platonov A.P., 2008, 26), which symbolizes his mother, who is known only by the fact that "a fisherman's wife was left - he was widowed". (Platonov A.P., 2008, 34). The lake is presented not only as feeding Sasha Dvanov, but his father fisherman as well who forages in the muddy water that is definitely a sinister symbol. This is a simple fact of death, even out of curiosity it is refuted by the text in the phrase "continuing his life" (Platonov A. P., 2008, 289). Moreover, "And there is a close, inseparable place for Alexander, where they await the return of the blood, that was once divided in the body of the father for his son, as eternal friendship" (Platonov A.P., 2008, 289)here A. Platonov clearly points to the place where Chagataev from "Dzhan" preferred to die staying "alive deliberately". The motive of his return to the womb or in the state of "unborn" in the text transcends the problem of death of every creature. Immersing himself in the original embryonic state, a person closes the loop of existence, making himself invulnerable and living forever. In this sense, the text of A. Platonov is indivisible into the layers of spiritual and vulgar materialist comprehension, the writer makes their complete fusion in a unique way. Like the formation of a new indivisible atom, A. Platonov's text generates the spirituality of the material in the spirit of the writer - "spirituality of the womb".

The texts of "Dzhan" and "Chevengur" being so different in emotional state from reading, in fact represent the same way that is passed in the first case, and in the second one it is not completed. But how is it possible to compare the gloomy "Chevengur", with the dead central characters and mass destruction of people, with a happy story "Dzhan", where the nation finds its place, becomes useful to society, and a raped and illiterate girl Aidym comes to Moscow to study? In Chevengur the process of looking for the mother is not completed, it just starts in A. Dvanov who enters the lake. Kopenkin dies in reality, but A. Platonov does not put the point in the novel. Zakhar Pavlovich, Alexander's foster-father, wants to find him, "Do you want me to give you a rouble note again? Just bring me Sasha. - I'll do it for free, - Prokofy promised and went to look for Dvanov" (Platonov A.P., 2008, 362). A novel does not end with the final death of Dvanov, his clever brother Prokofy leads him, he is already gone to look for him. "Chevengur" does not bury the idea of happiness, finishing grimly; it shows a further progress already out of the text. This is the return of Alexander, the main thinker, from the mother's interior.

\section{Conclusion}

The return to the mother, pre-rational state literally saves "spiritualized bodies" of Platonov's heroes, but a happy ending is possible when returning in a new capacity, overcoming the orphancy and gaining a sense of unity with other people, "Chagataev is now convinced that help will come only from someone else" (Platonov A.P., 2008, 20). Thus, the heterotopic analysis through categorical concepts of psychoanalysis allows us to understand the mechanism to overcome the orphancy as gaining happiness and immortality by passing through the mother. The process of objectification firstly from the mother, then the formation of the subject, returning to the mother, and finally finding it and returning in a new capacity is fully passed by Chagataev. A. Dvanov does not die, and gets a chance to continue living, and there is a hope for his return. Even Kopenkin, 
tending to the grave of Rosa, finds her dying the Soviet reality is deep and not obvious, like himself in reality. He is at the same space near a pre-Socratic philosophy of Heraclitus. That her - in the ground, in the grave. Even the is why the psychoanalytic treatment methods return of deceased Kopenkin is possible when to the repressed allow better understanding of reading the text in the light of the philosophy the Soviet mentality of the controversial 20-30s, of N. Fedorov. A. Platonov's representation of witnessed by Andrei Platonov.

\section{References}

Epshtein, M. Iazyk bytiia u A. Platonova [The language of existence by A. Platonov]. Available at: http://magazines.russ.ru/voplit/2006/2/ept9.html

Foucault, M. (1984). Of Other Spaces, Heterotopias. Architecture, Mouvement, Continuité. New York, 46-49.

Kristeva, J. Sily uzhasa: esse ob otvrashchenii [Powers of horror: the essay about disgust]. Available at: http://royallib.com/book/kristeva_yuliya/sili_ugasa_e .. (accessed 21 February 2016)

Nikolchina, M. (2003). Znachenie i matereubiistvo (Value and matricide). Moscow, $180 \mathrm{p}$.

Platonov, A.P. Chevengur (Chevengur). Available at: http://www.e-reading.club/book. php?book=45170 (accessed 21 February 2016)

Platonov, A.P. Dzhan (Dzhan). Available at: http://www.e-reading.club/book.php?book=45111 (accessed 21 February 2016)

Spiridonova, I.A. Motiv sirotstva v Chevengure A. Platonova v svete khristianskoi traditsii [The motive of orphancy in A. Platonov's "Chevengur" in the light of Christian tradition]. Available at: http://cyberleninka.ru/article/n/motiv-sirotstva-v-chevengure-a-platonova-v-svete-hristianskoytraditsii (accessed 21 February 2016). 


\title{
Преображение субъекта в акте «обратного рождения»: \\ анализ поиска утраченного материнского \\ (на материале текстов А. Платонова)
}

\section{О.А. Глушенкова}

Сибирский государственный технологический университет Россия, 660017, Красноярск, ул. Марковского, 57

\begin{abstract}
Статья посвящена онтологическому анализу текстов А. Платонова. Классическая тема сиротства, поднимаемая писателем, анализируется через понятийный аппарат Ю. Кристевой о поиске утраченного материнского. Проблема вытеснения европейской рациональностью материнского оставляет открытым вопрос о статусе этого «вытесненного» пространства. При анализе текста оно представлено понятием М. Фуко - гетеротопия, для кониептуализации скрытого, вытесненного пространства материнского в тексте. Анализируется стремление преодоления сиротства главными героями в эмочионально различных текстах “Джан” и “Чевенгур” не в тривиальном контексте соединения с отцом, а с позиции поиска матери и реализаџии ее нахождения возвращения в утробу - замыкания прочесса рождения и символического преодоления смерти. Апробируется использование категориальной базы психоанализа и философских понятий при анализе литературного текста. Различие двух анализируемых текстов в процессе преодоления сиротства репрезентирует стремление к построению счастливой утопии в советской действительности противоречивых 30-х годов.
\end{abstract}

Ключевые слова: гетеротопия, А. Платонов, психоанализ, советская действительность.

Научная специильность: 10.00.00 - филологические науки. 